\title{
MOMENTUM SAAT PANDEMI COVID-19
}

\author{
Hesti Murwaniputri \\ hesti.murwaniputri@feb.uncen.ac.id \\ Dosen Jurusan Manajemen Fakultas Ekonomi dan Bisnis Universitas Cenderawasih,
}

\begin{abstract}
Abstraksi:
Pandemi Covid 19 menyebabkan perekonomian dunia mengalami resesi tidak terkecuali Indonesia. Kinerja ekonomi yang melemah berdampak pada situasi pasar modal Indonesia yang ditunjukkan dengan penurunan IHSG diikuti dengan penurunan harga saham perusahaan, sehingga tidak sedikit investor menarik dana mereka untuk dialokasikan pada aset yang lebih aman. Ketika terjadi panic sell di pasar modal, oleh sebagian investor melihat bahwa pandemi merupakan sebuah momentum untuk mendapatkan saham-saham perusahaan yang memiliki fundamental baik, bervaluasi rendah dan memiliki prospek menjanjikan dimasa depan. Metodologi penelitian adalah studi literatur.
\end{abstract}

Kata Kunci : Covid 19, IHSG, Momentum.

\section{PENDAHULUAN}

\section{A. Latar Belakang}

Covid-19 adalah penyakit yang disebabkan oleh virus severe acute respiratory syndrome coronavirus 2 ( SARSCoV-2). Covid-19 dapat menyebabkan gangguan sistem pernapasan, mulai dari gejala yang ringan seperti flu, hingga infeksi paru-paru, seperti pneumonia. Kasus pertama penyakit ini terjadi dikota Wuhan, Cina, pada akhir Desember 2019. Setelah itu, Covid-19 menular antar manusia dengan sangat cepat dan menyebar kepuluhan Negara, termasuk Indonesia, hanya dalam beberapa bulan. Penyebaran yang cepat membuat beberapa Negara menerapkan kebijakan untuk memberlakukan lockdown untuk mencegah penyebaran virus Corona. Di Indonesia, pemerintah menerapkan kebijakan Pembatasan Sosial Berskala Besar (PSBB) untuk menekan penyebaran virus ini (https://www.alodokter.com/covid-19).

Pandemi Covid-19 telah memengaruhi berbagai sektor termasuk sektor ekonomi, Covid-19 "nyaris" menyebabkan perekonomian dunia mengalami resesi. Pada Kuartal I 2020, BPS melaporkan pertumbuhan ekonomi Indonesia hanya tumbuh sebesar 2,97 persen dibandingkan tahun lalu pada periode yang sama yaitu 5,02 persen, kemudian pada kuartal II 2020 pertumbuhan ekonomi minus 5,32 persen (https://www.kompas.com). Menteri Keuangan Sri Mulyani Indrawati mengatakan bahwa krisis yang diakibatkan virus Corona saat ini jauh lebih kompleks dibandingkan dengan krisis 1997-1998 dan 2008-2009, karena penyebabnya belum bisa ditahan (https://katadata.co.id/), saat Konferensi Pers tanggal 1 April 2020, Sri Mulyani memaparkan beberapa dampak yang diakibatkan oleh Covid-19 pada sektor ekonomi, antara lain (https://www.kemenkeu.go.id):

1. Ancaman gangguan kesehatan karena terinfeksi Covid-19 dan ancaman jiwa karena risiko tertular

2. Kehilangan pendapatan, bagi keluarga yang tidak mampu dan yang bekerja pada sektor informal.

3. Penurunan daya beli masyarakat dan konsumsi

4. UMKM tidak dapat melakukan kegiatan usahanya sehingga terganggu kemampuan memenuhi kewajiban kredit.

5. Sektor Korporasi yang terganggu aktivitas ekonominya, yang paling rentan: manufaktur, perdagangan, transportasi dan akomodasi (restoran dan perhotelan).

6. Memburuknya aktivitas ekonomi dan dunia usaha yang akan berpengaruh ke sektor keuangan seperti Perbankan dan perusahaan pembiayaan yang berpotensi mengalami persoalan likuiditas dan insolvency serta depresiasi rupiah, volatilitas pasar keuangan dan capital flight 


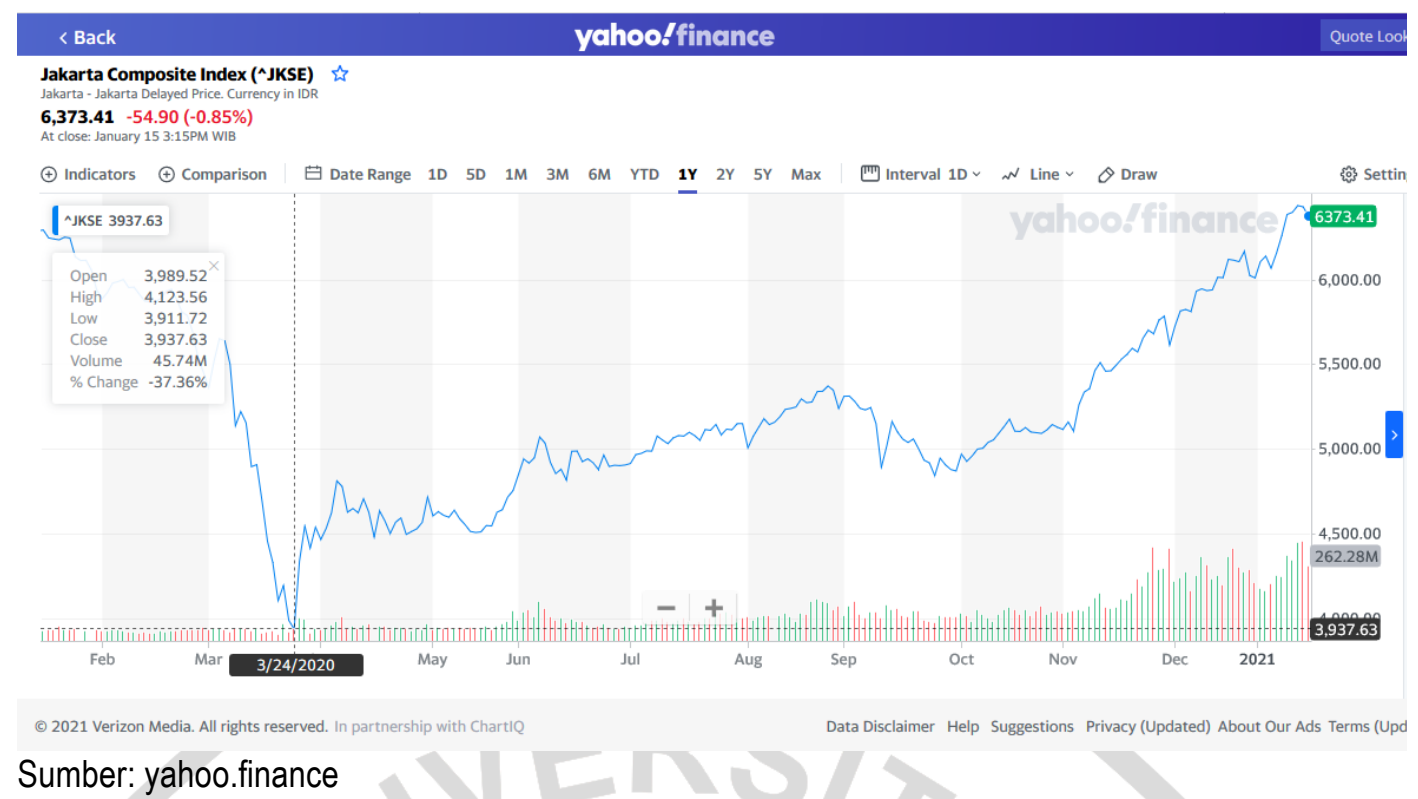

Gambar 1. Pergerakan IHSG dari Maret 2020-Desember 2020

Volatilitas pasar keuangan (pasar saham) ditunjukkan oleh pergerakan Indeks Harga Saham Gabungan (IHSG) yang terjun dengan sangat tajam pada bulan Maret 2020. gambar 1 menunjukkan penurunan IHSG yang sangat dalam pada 24 Maret 2020, dimana selama perdagangan pada hari itu IHSG bergerak pada kisaran 3.911,72-4.123,56 dan ditutup pada level 3.937,63 (terjadi penurunan 51,88 point). Bulan Maret merupakan penurunan IHSG terburuk, sejak masuknya virus Covid-19 ke Indonesia pada awal bulan Maret, IHSG telah mengalami kemerosotan. Pada senin 9 Maret 2020, IHSG terjun hingga 6,58 persen atau 361,73 point ke posisi 5.136 yang menyebabkan regulator dan pengawas pasar modal mengambil kebijakan penghentian perdagangan atau trading halt, kebijakan ini dilakukan karena khawatir kepanikan atas virus Corona membuat investor berbondong-bondong meninggalkan pasar modal. Atas kebijakan tersebut, jika terjadi penurunan yang sangat tajam dalam 1 hari, maka trading halt akan ditetapkan. Jika Penurunan IHSG mencapai sebesar 5 persen, maka akan dilakukan trading halt 30 menit, selain itu diberlakukan juga trading suspend bila IHSG turun hingga 15 persen (https://www.cnnindonesia.com/ekonomi).

Pada Mei 2020, indeks mulai recovery dan menapaki level 4.605. Diikuti dengan pergerakan pada bulan Juni yang menyentuh level 4.940. Pada Juli kenaikan indeks tidak terlalu signifikan, demikian juga dengan awal Agustus 2020. Namun pada akhir Agustus sampai dengan awal September 2020 index menunjukkan kenaikan yang cukup menggembirakan, bahkan menyentuh level 5.300 (https://money.kompas.com). Penurunan yang terjadi pada IHSG pada masa pandemi menyebabkan terkoreksinya harga saham perusahaan tidak terkecuali perusahaan-perusahaan bluechip dan menyebabkan panic selling diantara investor, Panic selling yang dilakukan oleh investor dikarenakan semakin merebaknya Covid-19 sehingga investor memilih memindahkan aset mereka pada aset yang lebih aman seperti emas.

\section{PEMBAHASAN}

Ditengah ketidakpastian ekonomi yang diakibatkan oleh pandemi Covid-19, membuat para investor melakukan panic sell, sehingga membuat harga saham perusahaan mengalami penurunan tajam termasuk saham perusahaan LQ45. Saat pandemi dapat dilihat secara berbeda oleh setiap investor, beberapa melakukan panic sell karena takut akan ketidakpastian ekonomi tetapi ada beberapa investor yang melihat bahwa saat pandemi merupakan sebuah momentum yang baik untuk mendapatkan perusahaan-perusahaan dengan fundamental baik dan memiliki valuasi yang murah, karena pandemi merupakan momentum yang "pas" untuk memperbaiki portofolio dengan tujuan jangka panjang (investasi) dan jangka pendek (trading). Seperti sektor keuangan (perbankan) yang memiliki peran yang penting dalam suatu negara untuk menjalankan perekonomian, meskipun sektor perbankan termasuk sektor yang ikut 
terpukul saat pandemi, dimana kebijakan pemerintah untuk mewajibkan setiap bank melakukan relaksasi kredit untuk membantu debitur yang terdampak pandemi dapat mengakibatkan kebangkrutan bagi pihak bank karena risiko kredit macet, biaya operasional yang lebih tinggi dari pendapatan, risiko pasar serta risiko likuiditas tetapi jika perekonomian telah berangsur-angsur pulih maka sektor perbankan akan rebound kembali karena pembayaran kewajiban yang harus dibayarkan. Salah satu perbankan yang terdampak pandemi adalah PT Bank Republik Indonesia, Tbk.

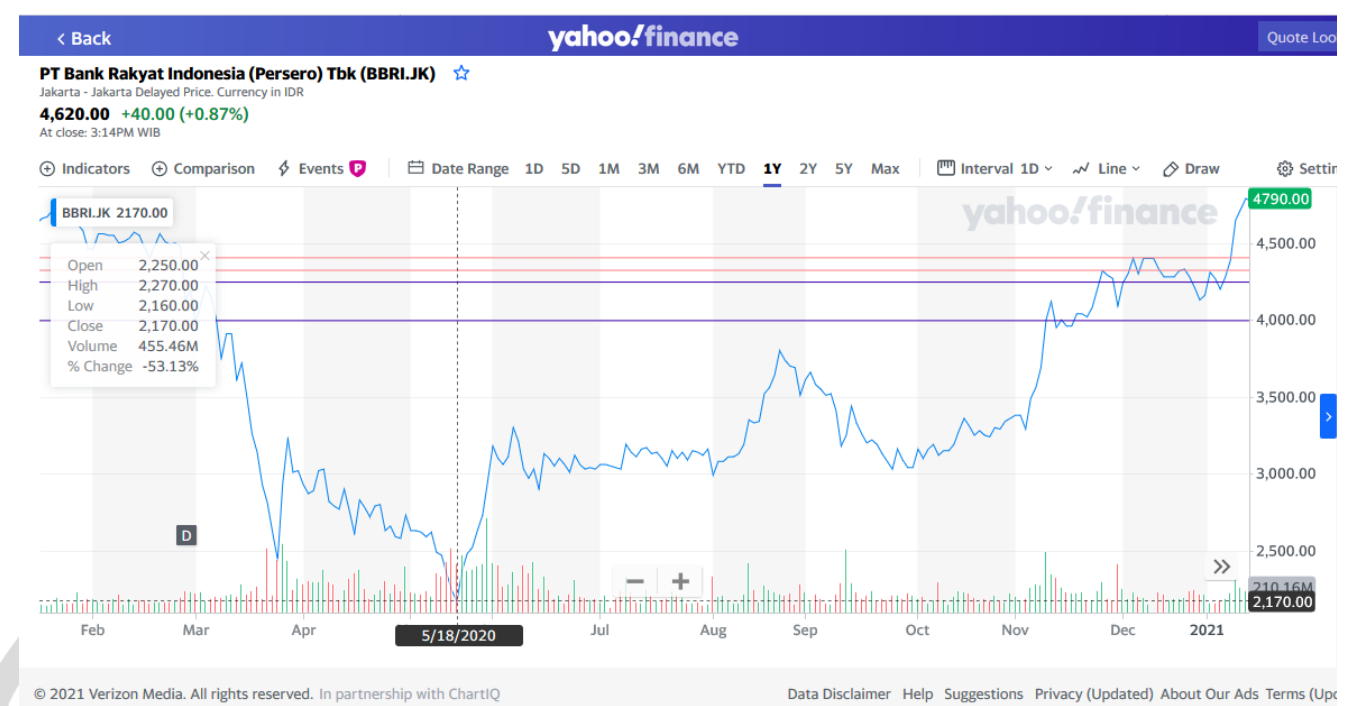

Sumber: finance.yahoo

Gambar 2. Pergerakan harga saham BBRI dari Maret 2020- Desember 2020

Tanggal 24 Maret 2020, harga saham BBRI ikut terkoreksi dalam di harga 2.440,00 (penurunan 140 point) seiring dengan terkoreksinya IHSG. Penurunan Tajam terjadi pada bulan Mei 2020, BBRI ditutup memerah yaitu 2.170 per saham. Aksi jual bersih oleh asing (net sell) Rp 216 Miliar di pasar reguler, saham yang paling banyak dijual (net sell) oleh asing adalah PT Bank Rakyat Indonesia (BBRI) sebanyak 33,81 Miliar yang menyebabkan saham ini terkoreksi sebesar 2,68 persen (https://www.cnbcindonesia.com) dengan total nilai saham BBRI ditransaksikan mencapai Rp 998.728.567.000 dan volume saham yang ditransaksikan 455.462 .600 lot (https://www.idx.co.id). Pada Bulan Mei 2020, tercatat BBRI merupakan saham dengan investor terbanyak dari Januari 2020 berjumlah 180 ribu menjadi 262 ribu (https://money.kompas.com). Pertumbuhan jumlah investor BBRI selain dikarenakan memiliki fundamental yang baik serta harga saham perusahaan yang sedang terkoreksi dinilai terjangkau bagi investor dengan modal terbatas.

Tabel 1. Rasio Keuangan BBRI

\begin{tabular}{|l|c|c|c|c|c|c|}
\hline & $31-M a r-20$ & $31-M a r-19$ & $30-J u n-20$ & $30-J u n-19$ & $30-S e p-20$ & $30-S e p-19$ \\
\hline NPL net & $0,63 \%$ & $1,05 \%$ & $0,77 \%$ & $1,12 \%$ & $0,78 \%$ & $1,13 \%$ \\
\hline CKPN & $5,09 \%$ & $3,27 \%$ & $4,72 \%$ & $3,49 \%$ & $5,10 \%$ & $3,66 \%$ \\
\hline LDR & $90,39 \%$ & $90,74 \%$ & $85,78 \%$ & $93,09 \%$ & $82,58 \%$ & $93,07 \%$ \\
\hline KPMM & $18,23 \%$ & $21,68 \%$ & $19,83 \%$ & $20,77 \%$ & $20,38 \%$ & $21,62 \%$ \\
\hline Laba Bersih & $8,17 \mathrm{~T}$ & $8,19 \mathrm{~T}$ & $10,2 \mathrm{~T}$ & $16,2 \mathrm{~T}$ & $14,2 \mathrm{~T}$ & $24,8 \mathrm{~T}$ \\
\hline
\end{tabular}

Sumber: www.idx.co.id

Otoritas Jasa Keuangan (OJK) telah merilis POJK Nomor 11/POJK.03/2020 tentang Stimulus Perekonomian Nasional sebagai Kebijakan Countercyclical. Debitur yang mendapatkan perlakuan khusus dalam POJK ini adalah debitur (termasuk debitur UMKM) yang mengalami kesulitan untuk memenuhi kewajiban pada bank karena debitur atau usaha debitur terdampak penyebaran virus corona, baik secara langsung ataupun tidak langsung pada sektor 
ekonomi (https://money.kompas.com), dan kembali memperpanjang kebijakan stimulus kredit hingga akibat Covid-19 yang tertuang dalam POJK Nomor 48 /POJK.03/2020 Tentang Perubahan Atas Peraturan Otoritas Jasa Keuangan Nomor 11/POJK.03/2020 Tentang Stimulus Perekonomian Nasional Sebagai Kebijakan Countercyclical Dampak Penyebaran Coronavirus Disease 2019, perpanjangan relaksasi kredit hingga 31 Maret 2022 dilakukan karena penyebaran Covid-19 masih berlangsung dan mempengaruhi kinerja debitur.

Relaksasi kredit dapat menjadi "bumerang" untuk perbankan, karena peningkatan resiko kredit perbankan akibat dari penurunan kinerja dan kemampuan debitur dalam memenuhi kewajibannya sehingga mengganggu kinerja perbankan yang akhirnya berdampak pada pertumbuhan ekonomi. Saat terjadi resesi, ada 3 risiko yang dihadapi oleh perbankan yaitu kredit macet, risiko pasar dan risiko likuiditas. Dapat dilihat pada Tabel 1 bahwa laba bersih kuartal I, II dan III 2020 mengalami penurunan dari tahun sebelumnya, disebabkan melambatnya pertumbuhan ekonomi karena pandemi, penurunan laba bersih mengakibatkan naiknya NPL net BBRI kuartal I, II dan III 2020, meskipun mengalami peningkatan tetapi NPL net masih dibawah regulator yang ditetapkan Bank Indonesia yaitu 5\%. Resiko pasar dilihat dari rasio CKPN, terlihat bahwa CKPN BBRI kuartal I, II dan III mengalami peningkatan dari rasio CKPN kuartal I, II dan III tahun 2019 artinya manajemen BBRI dapat mengantisipasi naiknya resiko pasar akibat resesi dengan menyiapkan cadangan laba yang lebih besar. Rasio likuiditas BBRI dilihat dari persentase rasio LDR semakin rendah dari kuartal I, II dan III 2020 masih berada pada batas aman LDR yang ditentukan Bank Indonesia antara 78\%-92\%, artinya semakin rendah LDR maka tingkat likuiditas semakin tinggi karena jumlah dana yang dibutuhkan untuk membiayai kredit semakin sedikit dan jumlah dana untuk melunasi kewajiban semakin banyak. Rasio KPMM BBRI menjelaskan mengenai ketersediaan ekuitas untuk membayar nasabah yang akan menarik dana, peraturan Bank Indonesia mengharuskan setiap bank mencatat KPMM minimal 8\%, artinya KPMM BBRI masih dalam batas yang aman. Dari fundamental BBRI diatas dapat disimpulkan walaupun karena kondisi ekonomi yang tidak stabil saat pandemi berakibat kinerja perusahaan menurun, perusahaan tidak akan mengalami kondisi gagal bayar ke nasabah.

\section{PENUTUP}

\section{A. Simpulan}

Fundamental yang baik mencerminkan kinerja perusahaan yang baik pula, walaupun pada saat resesi, perusahaan yang memiliki fundamental yang baik ikut terdampak tetapi saat keadaan ekonomi kembali pulih, maka perusahaan berfundamental baik akan rebound dengan cepat.

\section{B. Saran}

Investor selalu melihat fundamental perusahaan, valuasi harga dan prospek masa depan yang menjanjikan untuk investasi.

\section{DAFTAR PUSTAKA}

[1]. "Covid-19". alodokter.com. 20 Agustus 2020. https://www.alodokter.com/covid-19

[2]. "Jejak Batu Sandungan IHSG selama Covid-19. 30 November 2020. 30 November 2020. https://www.cnnindonesia.com/ekonomi/20201130201735-92-576354/jejak-batu-sandungan-ihsg-selamapandemi-covid-19

[3]. "Ini saham yang paling banyak investornya". 3 September 2020. 25 September 2020. https://money.kompas.com/read/2020/07/03/120800326/ini-saham-yang-paling-banyak-investornya?page=all

[4]. "Pandemi Covid-19, Apa saja dampak pada sektor ketenagakerjaan Indonesia?. kompas.com. 20 Agustus 2020. 20 Agustus 2020. https://www.kompas.com/tren/read/2020/08/11/102500165/pandemi-covid-19-apa-sajadampak-pada-sektor ketenagakerjaan-indonesia-?page=all

[5]. "Sri Mulyani Sebut Covid-19 Lebih Kompleks dari Krisis 1998 dan 2008". 7 April 2020. 18 Mei 2020. https://katadata.co.id/happyfajrian/finansial/5e9a41f631b5e/sri-mulyani-sebut-covid-19-lebih-kompleks-dari-krisis1998-dan-2008

[6]. "Langkah Penguatan Perlindungan Sosial dan Stimulus Ekonomi Menghadapi Dampak Covid-19. 1 April 2020. 10 April 2020. https://www.kemenkeu.go.id/media/14790/materi-konferensi-pers-1-april-2020.pdf 
[7]. "6 Bulan Pandemi Covid-19, Bagaimana Dampaknya Ke Pergerakan Saham Di Indonesia". 2 September 2020. 10 September 2020.https://money.kompas.com/read/2020/09/02/155619126/6-bulan-pandemi-covid-19-bagaimanadampaknya-ke-pergerakan-saham-di-indonesia?page=all.

[8]. "Relaksasi Kredit, Apa Untungnya Untuk Nasabah dan Industri Keuangan?". 31 Maret 2020. 10 April 2020. https://money.kompas.com/read/2020/03/31/205335926/relaksasi-kredit-apa-untungnya-untuk-nasabah-danindustri-keuangan

[9]. "Profit Taking, Lanjut Asing Keluar Lagi Bikin IHSG Merah". 18 Mei 2020. 18 Mei 2020. https://www.cnbcindonesia.com/market/20200518090647-17-159124/profit-taking-lanjut-asing-keluar-lagi-bikininsg-merah

[10]."Ringkasan Perdagangan”. 31 Maret 2020. 10 April 2020. https://www.idx.co.id/data-pasar/ringkasanperdagangan/ringkasan-saham/ 